\title{
Ecotourism principles as a framework for culturally responsive community development
}

\author{
A. Sarhan, R. Abdelgalil \& Y. Radwan \\ Department of Architectural and Environmental Design, \\ Arab Academy for Science, Technology and Maritime Transport, Egypt
}

\begin{abstract}
Ecotourism is one of the fastest growing sectors of tourism, denoting responsibility to the environment and a duty to respect and develop local cultures. Its development can cause positive and negative impacts, hence its premise is to find a balance between various impacts with an aim to preserve cultural integrity, ecological processes and biological diversity. This paper examines ecotourism as a form of sustainable development for Egyptian communities aiming to manage diverse resources such that economic, social and environmental needs are fulfilled. The case study lies in El-Omayyad biosphere reserve, a protected area designated by UNESCO in 1981. It lies in the western Mediterranean coastal desert of Egypt and possess a variety of flora, fauna and human settlements. The coastal area has witnessed a boom of resort construction, since the 1980s and continuing to date. The area has been divided into fractions of so called 'tourist villages'. These developments are occupied a mere couple of months per year and have ignored the economic, social and environmental fabric of the area. The reserve presents a further challenge, namely the Bedouin culture and the restrictions of a protected area. This research builds an appraisal tool able to capture the unique elements of the area, addressing the abovementioned challenges along with lessons learnt from the unresponsive recurring developments. To analyze the case study, data sets of physical characteristics, environmental, social and economic values were collated through governmental reports, prior research studies and field observations, corroborated by informal interviews with the locals to highlight crucial issues affecting tourism. For a comprehensive sustainable development in the area, the tool developed in this paper can be used by local government and organizations both in Egypt and other developing nations witnessing similar types of development in order to improve the physical and social environments.
\end{abstract}

Keywords: ecotourism, sustainable tourism development, north coast of Egypt, protected areas, Egypt desert, Al Omayyad biosphere reserve. 


\section{Introduction}

Tourism is unquestionably a crucial domain for economic development in Egypt and should be stimulated and endorsed [1]. Ecotourism as a sub-component of the field of sustainable tourism, carries apparent potential as an effective mean for sustainable development which is why developing countries are now implementing it in their economic development and conservation plans. Ecotourism, involves visiting natural areas in order to acquire, study, or perform environmentally friendly activities, based on the nature experience, which allows the economic and social improvement of local communities. It should also preserve a high level of tourist fulfillment and provide a meaningful experience to the tourists, increasing their responsiveness about sustainability issues and encouraging sustainable tourism practices amongst them [2]. The north coast of Alexandria remains one of the country's most impoverished areas and is characterized by extreme levels of jagged development growth [3, 4]. The north coast is a frontier of social and ecological diversity, potential and economic opportunity, which could significantly benefit from tourism development. This paper will propose a comprehensive framework integrating economic, environmental and social issues surrounding the implementation of an ecotourism industry. Allowing a destination to gain an initial view of their tourism industry and the areas in which further research and development need to take place, a set of guidelines and recommendations for the establishment of an ecotourism urban development proposal is concluded from this paper.

\subsection{Coastal tourism on the north coast in Egypt}

Tourism development is distributed over the Egyptian coasts in three main regions: the Sinai region; the Red Sea region; and the Mediterranean coastal region. The Northwestern coastal region is one of the most important tourist regions of Egypt. It ranges about 500 kilometers along the Mediterranean coastline from Alexandria to Al Salloum cities [5]. The region is divided into the coastal strip, and the upland, by a coastal highway. The coastal area includes several tourist villages while the upland includes some isolated Bedouin settlements [3].

\subsection{The main problem}

The coastal area has witnessed an explosion of resort construction, since the 1980s and continuing to date. The area has been divided into fractions of so called 'tourist villages' which lack the facilities that attract tourists, and are occupied by middle and upper middle class residents of Cairo, Alexandria, and other towns in the Nile Delta. The resorts are used a maximum of three to four months of the year, ignoring the economic, social and environmental fabric of the area. Al Omayyad Biosphere Reserve (OBR) presents a further challenge, namely the nomad culture and the limitations of a protected area [6]. Ecotourism is a viable form of development for the area, yet the area is dominated by traditional and damaging developments. 


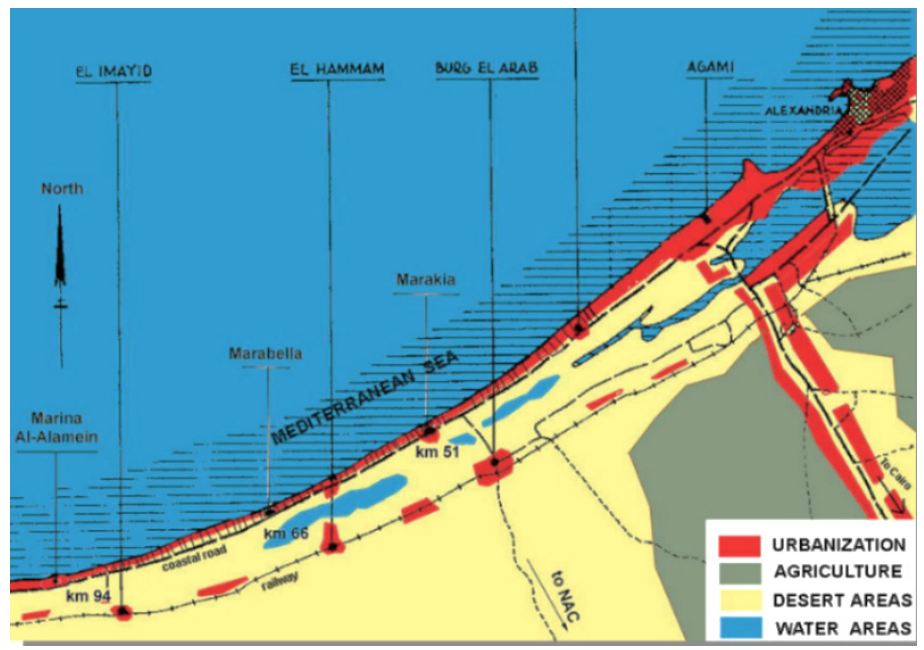

Figure 1: Actual development along the NWC and the Back land settlements.

\subsection{Challenges}

Traditional tourism places direct pressure on the ecosystems causing degradation of the physical environment and disturbance to wildlife, mostly developed in isolation from the development of communities [6]. The ecosystems are affected due to the construction of accommodation, visitor centers, infrastructure, and other services that have a direct impact on the environment, in the form of vegetation removal, animal disturbance, elimination of habitats, soil erosion, noise or visual disturbance and uncontrolled waste management. These impacts can last beyond the time of an initial project implementation and affect future sustainability for the destination tourism activities [7]. Protection of the resources requires altering people's behavior. Awareness of the locals has an essential role, through environmental awareness, wide system interventions, and a connection between local community, investors, and administrative authorities. Tourism exerts substantial stress on host communities, including the interruption of local traditions and lifestyle and changes in social, economic and traditional daily life routines. Also the interaction with the tourism activities and the boom in migration of the local population to other cities to work threatens the integrity of the local environment. The uninformed foreigners about local social system can also weaken preexisting social relationships and values [6].

\section{Ecotourism sustainable development}

Ecotourism is a subcomponent of sustainable tourism, based upon nature travel. The International Ecotourism Society (TIES) defines ecotourism as: "responsible travel to natural areas that conserves the environment and improves the welfare of local people." [8]. In any definition used, ecotourism must have a positive impact on both natural areas and the local community. 


\subsection{Environmental sustainability}

Ecotourism occurs in, and depend on a natural setting. A strategic feature is education and interpretation of this natural environment and any linked cultural manifestation. Since environmental sustainability is often the only characteristic which is publically witnessed by using resources more sustainably, maintaining biodiversity and reduction of over-consumption and waste thus avoiding the expenses of reestablishing long-term environmental damages and contributing to the quality of tourism is essential [7]. Pure ecologically sustainable tourism is the maximum number of tourists that can be received within the habitat at the same time without any ecological harm [9], by means of reducing the waste produced or using energy in a conservative way. To support the tourism activity, infrastructure is laid out, including roads, airports, utilities, and sewage system etc. Also, constructions like Eco lodges, restaurants, education centers. To develop these infrastructures environmental alterations take place but their impact can be minimized by an environmental sensitive design and planning [9]. The OBR is already undergoing a serious transformation process form natural rangelands to agricultural lands, due to the extension of an irrigation canal and an extended irrigation networks from the Nile [10].

\subsection{Social sustainability}

It refers to the capability of a community to adapt to its functions and to engage inputs, such as big numbers of people, for a period of time, and continue functioning and contributing without the creation of social disharmony [10]. It also refers to creating more significant tourism experiences and visitor observation trips. The area holds much potential for such trips for example the Moghra Oasis in the upland of OBR, a small uninhabited oasis situated about $45 \mathrm{~km}$ south of Al Omayyad and centered by a brackish water lake with rare species [10]. Social already divisions or the exacerbation of already existing divisions is a crucial issue [11]. By recruiting and involving the local inhabitants in the process of development, it helps to boost the quality of tourism sectors. It is essential to include the equity and poverty alleviation of inhabitants' livelihoods in any development strategy. That is why social aim needs to add a protective tactic which will reduce the vulnerability and improve equity to ensure the satisfaction of primary social needs of the inhabitants [9].

\subsection{Economic sustainability}

Economic sustainability entails ensuring the vitality, effectiveness and efficiency of businesses, and their ability to generate income by using the available assets and resources in the best way to get the maximum output for a long term [12]. Sustainability in this principle refers to a level of economic gain from tourism sufficient to either cover the cost of any procedures taken to provide for tourism and to mitigate the outcome of the tourist's existence, or to offer a minor income enough to mitigate the inconvenience caused to the local community [11].

By the ability to produce goods and amenities on a continuous base, to maintain controllable levels of government and external debt, and to avoid extreme sectorial 
inequalities [13]. It is about assuring that income generated is channelled to the local area and not completely diverted to the multinational chains.
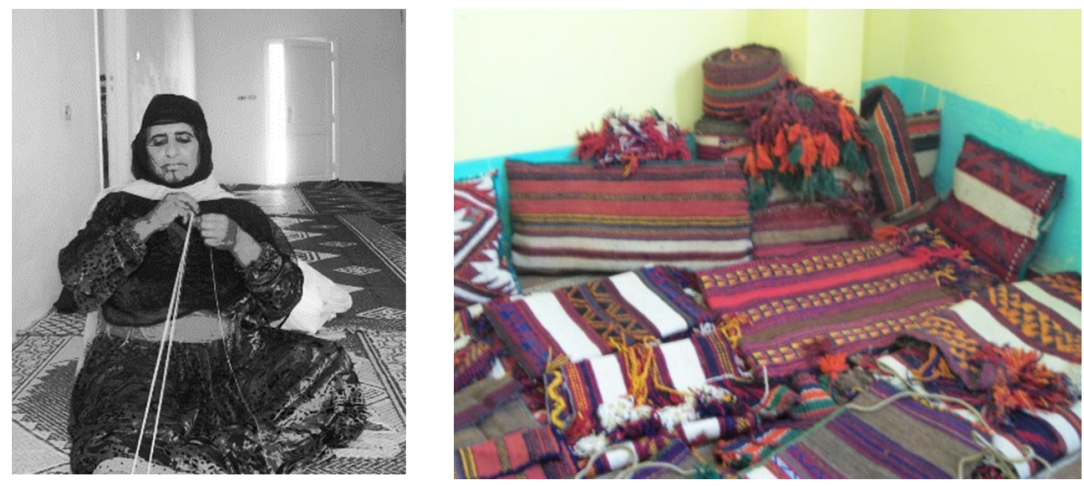

Figure 2: Income generating activities for women at OBR.

\subsection{Principles for ecotourism sustainable development}

Since ecotourism was initially just an idea, not a discipline, many businesses and governments endorsed it without understating its basic principles. Establishing internationally and nationally accepted guidelines and certifications proceeded throughout the 1990s [14]. A number of NGOs and governmental local authorities have suggested different sets of guidelines or principles for ecotourism. The Tourism Concern and Worldwide Life Fund Organization (1991), Green Globe 21 International Ecotourism Standard (2004), The International Ecotourism Society (2010) and the Quebec Declaration on Ecotourism (2002), each produced ecotourism principles. These principles were compared and common ones between all sets were drawn out. In alliance with the 12 renowned aims for sustainable tourism development recommended by the UNWTO, a framework was assembled (see Table 1), where common principles from the abovementioned sets were classified under each aim. A criticism leveled at the UNTWO 12 aims is that it does not quite balance the three dimensions of sustainability. The research grouped the aims and found 3 dedicated to the economic dimension, 5 to the social and 4 to the environmental. Another issue is that all aims carry similar weight, with no particular order or priority, which does not help when prioritizing action is needed, more so in developing countries. The research uses the lists of aims as a base to gauge the direction of ecotourism principles of the abovementioned sets and develops a framework which is relevant to protected areas in a developing context. The majority of the principles were found to be concentrating on the environmental and social sustainability criteria with nearly equal balance, according to the number of principles that were stated by each organization. The following environmental aims match the principles; physical integrity, biological diversity (most cited), resource efficiency and environmental purity. As for the social dimension it included social equity, visitor fulfillment, local control and 
Table 1: Principles for sustainable tourism development and aims of sustainable tourism development - comparative table.

\begin{tabular}{|c|c|c|c|c|c|}
\hline & AIMS & \multicolumn{4}{|c|}{ ECOTOURISM PRINCIPLES } \\
\hline 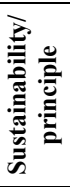 & $\begin{array}{c}\text { Aims of } \\
\text { Sustainable } \\
\text { Tourism } \\
\text { Development } \\
\text { (UNWTO) }\end{array}$ & $\begin{array}{c}\text { Tourism } \\
\text { Concern and } \\
\text { The World } \\
\text { Wildlife Fund } \\
\text { for Nature } \\
(1991)\end{array}$ & $\begin{array}{l}\text { The Green } \\
\text { Globe } 21 \\
\text { International } \\
\text { Ecotourism } \\
\text { Standard, } \\
(2004)\end{array}$ & TIES' (2010) & $\begin{array}{c}\text { Quebec } \\
\text { Declaration on } \\
\text { Ecotourism } \\
(2002)\end{array}$ \\
\hline \multirow{3}{*}{ 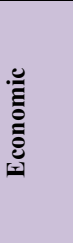 } & $\begin{array}{l}\text { 1. Economic } \\
\text { viability }\end{array}$ & $\begin{array}{l}\text { Undertaking } \\
\text { research }\end{array}$ & $x$ & $\mathrm{x}$ & $x$ \\
\hline & 2. Local prosperity & $\begin{array}{l}\text { Supporting } \\
\text { local } \\
\text { economies }\end{array}$ & $\begin{array}{l}\text { Provide ongoing } \\
\text { contributions to } \\
\text { the local } \\
\text { community }\end{array}$ & $\begin{array}{l}\text { Provide } \\
\text { empowerment to } \\
\text { the locals }\end{array}$ & \\
\hline & $\begin{array}{l}\text { 3. Employment } \\
\text { quality }\end{array}$ & $\mathrm{X}$ & $\mathrm{x}$ & $\mathrm{x}$ & $\mathrm{x}$ \\
\hline \multirow{5}{*}{. } & 4. Social equity & $\mathrm{x}$ & $\mathrm{x}$ & $\begin{array}{l}\text { Provide financial } \\
\text { benefits for local } \\
\text { people; }\end{array}$ & $\begin{array}{l}\text { Contributes to } \\
\text { their wellbeing }\end{array}$ \\
\hline & $\begin{array}{l}\text { 5. Visitor } \\
\text { fulfillment }\end{array}$ & $\begin{array}{l}\text { Marketing } \\
\text { tourism } \\
\text { responsibly }\end{array}$ & $\begin{array}{l}\text { Consistently } \\
\text { meets consumer } \\
\text { expectations } \\
\text { Be marketed } \\
\text { honestly } \\
\end{array}$ & $\begin{array}{l}\text { Positive } \\
\text { experience to the } \\
\text { tourists }\end{array}$ & $\mathrm{x}$ \\
\hline & $\begin{array}{l}\text { 6. Community } \\
\text { wellbeing }\end{array}$ & $\mathrm{X}$ & $\mathrm{x}$ & $\mathrm{X}$ & $\mathrm{X}$ \\
\hline & 7. Local control & $\begin{array}{l}\text { Involving local } \\
\text { communities } \\
\text { Training staff }\end{array}$ & $\mathrm{x}$ & $\begin{array}{l}\text { Training staff for } \\
\text { educational } \\
\text { purposes }\end{array}$ & $\begin{array}{l}\text { Includes local } \\
\text { and indigenous } \\
\text { communities in } \\
\text { its planning } \\
\text { and operation }\end{array}$ \\
\hline & $\begin{array}{l}\text { 8. Cultural } \\
\text { richness }\end{array}$ & $\mathrm{x}$ & \begin{tabular}{|l} 
Be sensitive to \\
interpret and \\
involve existing \\
cultures
\end{tabular} & $\begin{array}{l}\text { Protection and } \\
\text { awareness of the } \\
\text { cultural heritage. }\end{array}$ & $\begin{array}{l}\text { Contributes } \\
\text { actively to the } \\
\text { conservation of } \\
\text { cultural } \\
\text { heritage }\end{array}$ \\
\hline \multirow{4}{*}{ 全 } & $\begin{array}{l}\text { 9. Physical } \\
\text { integrity }\end{array}$ & $\begin{array}{l}\text { Integrating } \\
\text { tourism into } \\
\text { planning }\end{array}$ & $\begin{array}{l}\text { Provide } \\
\text { opportunities to } \\
\text { experience } \\
\text { nature in ways } \\
\text { that lead to more } \\
\text { understanding, } \\
\text { and appreciation }\end{array}$ & $\mathrm{x}$ & $\begin{array}{l}\text { Interprets the } \\
\text { natural and } \\
\text { cultural } \\
\text { heritage to } \\
\text { visitors }\end{array}$ \\
\hline & $\begin{array}{l}\text { 10. Biological } \\
\text { diversity }\end{array}$ & $\begin{array}{l}\text { Maintain } \\
\text { biodiversity }\end{array}$ & $\begin{array}{l}\text { Contributes } \\
\text { directly to the } \\
\text { conservation of } \\
\text { natural areas }\end{array}$ & $\begin{array}{l}\text { Conserving and } \\
\text { enhancing bio- } \\
\text { cultural diversity } \\
\text { and helps protect } \\
\text { nature }\end{array}$ & $\begin{array}{l}\text { Contributes } \\
\text { actively to the } \\
\text { conservation of } \\
\text { natural heritage }\end{array}$ \\
\hline & $\begin{array}{l}\text { 11. Resource } \\
\text { efficiency }\end{array}$ & $\begin{array}{l}\text { Using } \\
\text { resources } \\
\text { sustainably } \\
\end{array}$ & $\mathrm{x}$ & Minimize impacts & $x$ \\
\hline & $\begin{array}{l}\text { 12. Environmental } \\
\text { purity }\end{array}$ & $\begin{array}{l}\text { Reducing over } \\
\text { consumption } \\
\text { and waste }\end{array}$ & $\begin{array}{l}\text { Focus on giving } \\
\text { visitors the } \\
\text { opportunity to } \\
\text { personally and } \\
\text { directly } \\
\text { experience } \\
\text { nature }\end{array}$ & $\begin{array}{l}\text { Build environ- } \\
\text { mental awareness } \\
\text { and respect to } \\
\text { raise sensitivity to } \\
\text { the host culture }\end{array}$ & $\mathrm{x}$ \\
\hline
\end{tabular}


cultural richness, whereas community wellbeing was largely ignored. The economic sector was given the least importance in the studied sets, where stated 1 principle covering the economic criteria. Local prosperity was mentioned whereas economic viability and employment quality were largely ignored. It is concluded from the framework below that the sustainable tourism agenda is a broad one, thus reprioritizing the aims of sustainable tourism development is a crucial issue in the scope of work as the case study is in a developing country and most of the lists found were published from in developed countries with different cultural exposure and backgrounds, therefore most of the lists were more considerate to the environmental measure. In developing country context and reflecting on the case study, giving more importance to the local needs is pertinent be it economic, social or environmental. The priority for development should not undermine the natural resources where the major idea of ecotourism is built upon, so for further analysis a reprioritization of the categories should be followed due to the economic and social state of the area.

\section{Case study}

\subsection{Study area}

El Omayyad region lies at the western coastal desert of Egypt, and positioned at about $80 \mathrm{~km}$ to the west of Alexandria with coordinates $\left(29^{\circ} 00^{\prime}-29^{\circ} 18^{\prime} \mathrm{E}\right.$ and $\left.30^{\circ} 52^{\prime}-20^{\circ} 38^{\prime} \mathrm{N}\right)$. Covering a complete area of 75,800 ha it extends about $30 \mathrm{~km}$ along the Mediterranean coast from west El-Hammam to El-Alamein with a width of $23.5 \mathrm{~km}$ to the south. It was designated as a biosphere reserve in 1981 and extended in 1998 [10]. It is home to a diversity of habitats, biological communities, land use patterns and human settlements of the Mediterranean coastal desert of Egypt., comprising four villages with a total number of about 8000 inhabitants. This zone has a vivid coastline with white sandy beaches and pristine water, in addition to the historic Monuments alongside this coast which could have been used as major tourism attractions.

\subsection{Resources}

In El-Omayyad Biosphere (OBR), the topography consists of limestone ridges, coastal dunes, steep depressions and a huge inland plateau [15]. A total of 251 plant species were documented in the Reserve, around 70 bird species, 30 species of reptiles and amphibians as well as a diverse species of insects, where more than 600 were recorded [10]. The most important species of mammals include Dorcas gazelle, the Eastern Mediterranean endemic mole rat, Gerbils, Fennec, Red fox and the North African endemic. Water resources include Ground water and runoff water which is the main source to the south of Khashm El-Eish hill directly at its Northern sloping surface and the Nile water (extended canal) [10]. The OBR's significance lies in that it is the only protectorate in the north coast Mediterranean area and one of the 25 declared Protectorates in Egypt [16]. 


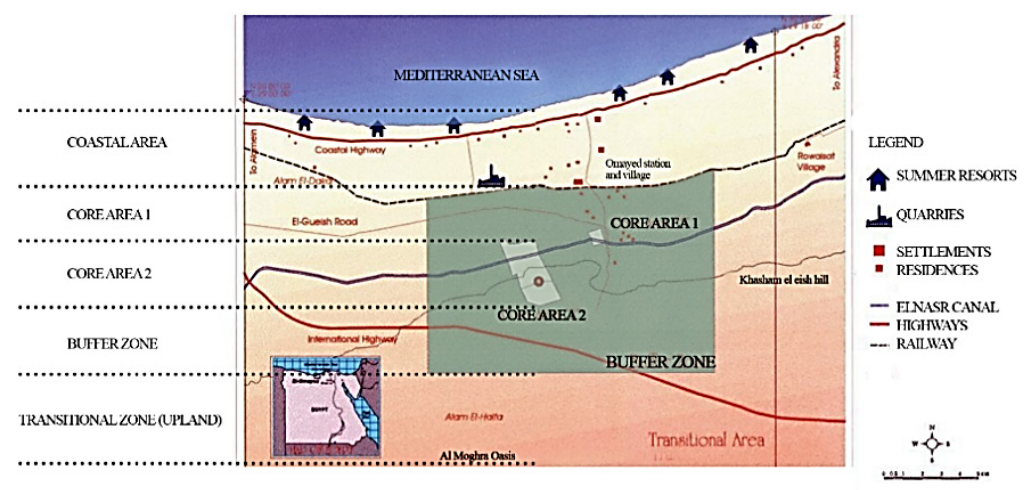

Figure 3: $\quad$ Location of the Omayyad (OBR) and its structure.

Table 2: Population and families in the four villages within the Omayed biosphere reserve.

\begin{tabular}{|c|c|c|c|}
\hline $\begin{array}{c}\text { Village } \\
\text { name }\end{array}$ & $\begin{array}{c}\text { Number } \\
\text { of families }\end{array}$ & $\begin{array}{c}\text { Number of } \\
\text { population }\end{array}$ & $\begin{array}{c}\text { Age } \\
>30\end{array}$ \\
\hline Omayed & 195 & 1600 & 640 \\
Sahel El Omayed & 112 & 1280 & 490 \\
Shammamah & 68 & 660 & 220 \\
Awlad Gebreil & 60 & 465 & 120 \\
Total & & 4000 & \\
Average & & 1470 & \\
\hline
\end{tabular}

\subsection{Analysis of Al Omayyad biosphere reserve area}

According to the study of the site the following constraints were observed. Environmental constraints included, the loss of biodiversity, and habitat fragmentation, there is an over water pumping process taking place for irrigation purpose, affecting the quality and quantity of ground water. Also almost all desert woody perennials are cut for fuel by the locals. This present natural land transformation taking place, is significantly affecting the physical and biological properties of habitats, increasing the pressure on the fragile dry soils leading to an increased rate of, reduction of resources, soil erosion and loss of productivity [10]. Socio-economic constraints are related to the environmental constraints where alteration of land and the availability of irrigation water has significantly affected the livelihoods of the community, increased internal conflicts between the local tribes in the land tenancy due to the rise in land prices. Land ownership is determined by ancestral heritage from the local community, where each tribe, according to the local Bedouin law (Urf), knows its land in terms of location and size, and has full control over it. Investors who desire to buy land, first have to buy the land from the local family then pay taxes per meter squared, according to government law [17]. The Bedouin communities suffer due to the absence of 
permanent source of income as their activities are seasonal like agriculture increasing the rate of unemployment and thus poverty leaving the economic state of the inhabitants in a very low level [10]. The situation calls for urgent assessment measures, analysis and management intervention towards sustainability.

\subsection{Deduced and prioritized guidelines}

A set of guidelines is proposed for a sustained development of an ecotourism industry in the site, according to the analytical framework and analysis of the case study area. The guidelines are listed consequently in Table 3 referenced to other ecotourism successful practices in other sites. Each aim has been fully integrated and guidelines developed for each, overcoming shorthand in the reviewed principles, which ignored the economic measure at large and some social aspects, which have been deemed very important for a comprehensive ecotourism development.

Table 3: Al Omayyad biosphere ecotourism development guidelines.

\begin{tabular}{|c|c|}
\hline $\begin{array}{l}\text { AIMS OF SUSTAINABLE TOURISM } \\
\text { DEVELOPMENT (UNWTO) } / \\
\text { PRINCIPLES OF ECOTOURISM }\end{array}$ & $\begin{array}{c}\text { OBR ECOTOURISM COMMUNITY DEVELOPMENT } \\
\text { GUIDELINES (authors) }\end{array}$ \\
\hline $\begin{array}{l}\text { 1. ECONOMIC VIABILITY } \\
\text { - Undertaking research }\end{array}$ & $\begin{array}{l}\text { - Feedback on client satisfaction through surveys for a sustained } \\
\text { project }\end{array}$ \\
\hline $\begin{array}{l}\text { 2. LOCAL PROSPERITY } \\
\text { - Provide ongoing contributions to locals } \\
\text { - Provide empowerment for the locals. } \\
\text { - Supporting local economies }\end{array}$ & $\begin{array}{l}\text { Developing traditional practices and income generating activities, } \\
\text { by involving women, with provision of crafting equipment to } \\
\text { provide alternative income opportunities which reduce poverty and } \\
\text { increase capital investment } \\
\text { - Production of jam and dried fruits from fig plants }\end{array}$ \\
\hline 3. EMPLOYMENT QUALITY & $\begin{array}{l}\text { - Adequate level of pay, conditions of service and availability to all } \\
\text { without discrimination by gender, race, etc. }\end{array}$ \\
\hline $\begin{array}{l}\text { 4. SOCIAL EQUITY } \\
\text { - Contributes to their well being } \\
\text { - Provide financial benefits for local people }\end{array}$ & $\begin{array}{l}\text { - Supplies for lodges are sourced locally } \\
\text { - Employ locals in the industry. } \\
\text { - Fair distribution of revenues }\end{array}$ \\
\hline $\begin{array}{l}\text { 5. VISITOR FULFILLMENT } \\
\text { - Marketing tourism responsibly } \\
\text { consistently meets customer expectations } \\
\text { - Positive experience to the tourists }\end{array}$ & $\begin{array}{l}\text { - Prepared maps and brochures } \\
\text { - Signage } \\
\text { - Reference material }\end{array}$ \\
\hline 6. COMMUNITY WELLBEING & $\begin{array}{l}\text { - Access to resources easily, amenities and life support systems, } \\
\text { - Avoiding any form of social degradation or exploitation. }\end{array}$ \\
\hline $\begin{array}{l}\text { 7. LOCAL CONTROL } \\
\text { - Includes local and indigenous } \\
\text { communities in its development and } \\
\text { operation travelers } \\
\text { - Training staff for educational purposes }\end{array}$ & $\begin{array}{l}\text { - Capacity building activities and workshops for the locals } \\
\text { - Transportation is provided by local Bedouins } \\
\text { - Informative evenings with staff } \\
\text { - Informative commentary by expert staff }\end{array}$ \\
\hline $\begin{array}{l}\text { 8. CULTURAL RICHNESS } \\
\text { - Contributes actively to the conservation } \\
\text { of cultural heritage } \\
\text { - Protection and awareness of the cultural } \\
\text { heritage. } \\
\text { - Interpret and involve cultures of the area }\end{array}$ & $\begin{array}{l}\text { - Well stocked library } \\
\text { - Heritage of site displayed } \\
\text { - Arabian village communities' services and introduction of the } \\
\text { Bedouin life programs. }\end{array}$ \\
\hline $\begin{array}{l}\text { 9. PHYSICAL INTEGRITY } \\
\text { - Provide opportunities to experience } \\
\text { nature in ways that lead to greater } \\
\text { understanding \& appreciation } \\
\text { - Integrating tourism into planning }\end{array}$ & $\begin{array}{l}\text { - Guided early morning walks } \\
\text { - Adventure activities } \\
\text { - Low cost environmental education center }\end{array}$ \\
\hline
\end{tabular}


Table 3: $\quad$ Continued.

\begin{tabular}{|c|c|}
\hline $\begin{array}{l}\text { AIMS OF SUSTAINABLE TOURISM } \\
\text { DEVELOPMENT (UNWTO) / } \\
\text { PRINCIPLES OF ECOTOURISM }\end{array}$ & $\begin{array}{l}\text { OBR ECOTOURISM COMMUNITY DEVELOPMENT } \\
\text { GUIDELINES (authors) }\end{array}$ \\
\hline $\begin{array}{l}\text { 10. BIOLOGICAL DIVERSITY } \\
\text { - Maintain biodiversity } \\
\text { - Contributes directly to the conservation } \\
\text { of natural areas } \\
\text { - Conserving and enhancing bio-cultural } \\
\text { diversity and helps protect the natural } \\
\end{array}$ & $\begin{array}{l}\text { - Rehabilitation of degraded ecosystems by propagation of } \\
\text { endangered species; } \\
\text { - Animal breeding centers } \\
\text { - Scientific research center } \\
\text { - Camel farms }\end{array}$ \\
\hline $\begin{array}{l}\text { 11. RESOURCE EFFICIENCY } \\
\text { - Using resources sustainably } \\
\text { - Minimize impacts }\end{array}$ & $\begin{array}{l}\text { - Provision of fresh drinking water by installation of solar water } \\
\text { desalination systems } \\
\text { - Use of solar heaters and cookers as a replacement of fuel wood } \\
\text { cutting. } \\
\text { - Water irrigation schemes } \\
\text { - Sustainable farming practices }\end{array}$ \\
\hline $\begin{array}{l}\text { 12. ENVIRONMENTAL PURITY } \\
\text { - Focus on giving visitors the opportunity } \\
\text { to personally experience nature } \\
\text { - Build environmental awareness and } \\
\text { respect to raise sensitivity to the host } \\
\text { culture } \\
\text { - Reducing over consumption and waste }\end{array}$ & $\begin{array}{l}\text { - Raising conservation awareness programs } \\
\text { - Clean up campaigns and educational programs } \\
\text { - Using local materials for site buildings and development of Eco } \\
\text { lodges } \\
\text { - Recycling }\end{array}$ \\
\hline
\end{tabular}

\section{Conclusions and recommendations}

The coastline is a limited resource, encouraging development alongside the coastal strip was not a successful plan. This approach is established to improve economical activities, such as agriculture, environmentally friendly industries and domestic handicraft activities. This paper suggests a comprehensive proposal of guidelines for ecotourism development of the coastal line and upland region for the OBR. The finest area for ecotourism development is not always along the sea, this is due to the strong prevailing winds along the coastline which cause discomfort in exposed locations and is used only in a couple of months. Creating destinations of interest in the upland location providing connections from all coastal areas is recommended. Bedouin people of the region are an important partner in the ecotourism plan; their values and ways of life must be respected, particularly as there are cultural restricting them from being totally involved in the tourism industry. Local residents must agree and be able to share their values and expertise with tourists to have a secure source of income that can help them sustain their daily routines like agriculture and olive oil production, handmade fabric crafts by women and animal herding. Ecotourism is an appropriate tool to accomplish national development goals. The north west coast of Egypt is a promising area for development, able to offer an abundant economic provision to the community and to the national economy, if it is suitably managed, developed and sustained. 


\section{References}

[1] Baedekers, "Toward a strategy of cultural and ecotourism in Egypt," Egyptian Travel Handbook, 2000.

[2] UNEP, 2015. [Online]. Available: http://www.unep.org/resourceefficiency /Business/SectoralActivities/Tourism/FactsandFiguresaboutTourism/Defin itions/tabid/78773/Default.aspx. [Accessed 32 2016].

[3] S. S. A. Magda Metwally, "An Approach to Sustainable Tourism Development in Coastal Area - Egypt," Housing and Building Research Center, Egypt, 2008.

[4] R. Abdel Galil \&. S.Salama, "South Mediterranean coastal landscape; lush lawns versus native species. A case study of the North Western coast of Alexandria, Egypt." in The Global Climate Change, Biodiversity and Sustainability International Conference, Alexandria, 2013.

[5] "Comparison between the North West Coast of Egypt and the LanguedocRoussillion of France".

[6] E. A.-S. Gouda, "Problems that Impede Sustainable Tourism Development in Egypt," International Journal of Social, Behavioral, Educational, Economic, Business and Industrial Engineering, vol. 6, no. 11, p. 8, 2012.

[7] S. Obenaus, "Ecotourism - Sustainable Tourism in National Parks and Protected Areas," 2005.

[8] "The International Ecotourism Society," [Online]. Available: http://www.ecotourism.org/ [Accessed 44 2016].

[9] J. K. Saha, "Sustainable Development in Ecotourism: Perspective of Bangladesh," Centria University of Applied Sciences, 2014.

[10] B. B. Salem, "Omayed Biosphere Reserve and its surrounding neighbourhood," University of Alexandria, National Committee for the UNESCO-MAB Programme, 2012.

[11] M. Mowforth and I. Munt, Tourism and sustainability, fourth ed., Newyork: Routledge, 2016.

[12] wiseGEEK http://www.wisegeek.org/what-is-economic-sustainability.htm 2003. [Online]. [Accessed 204 2016].

[13] A. L. Ayotte, "Ecotourism as a form of sustainable development in South Africa," Kingston, Ontario, Canada, 2009.

[14] T. Kiper, "Role of Ecotourism in Sustainable Development," in Advances in Landscape Architecture, Turkey, Intech, 2002, p. 30.

[15] "Egypt travel," 2016. [Online]. Available: http://en.egypt.travel/ attraction/index/el-omayed-biosphere-reserve. [Accessed 214 2016].

[16] Wikipedia [Online]. Available: https://en.wikipedia.org/wiki/Egyptian Protectorates. [Accessed 55 2016].

[17] UNESCO, "Innovative ways for a sustainable use of drylands," United Nations Educational,Scientific and Cultural Organization, Paris, 2014.

[18] UEP and UNWTO, "Making Tourism More Sustainable - A Guide for Policy Makers," UN World Tourism Organisation, 2014. 